\title{
Ethno-Therapeutic Remedies for Bone Fracture, Dang Dt. Gujarat. India.
}

\author{
${ }^{1}$ Thresia Paul, ${ }^{2}$ M.M. Prajapati; \\ ${ }^{I}$ Department of Botany, JJT University, Rajasthan \\ ${ }^{2}$ Departments of Botany, Science College Himatnagr, Gujarat-383 001
}

\begin{abstract}
The medicine men have their own home remedies to treat bone fracture. Out of the 42 interviewed 15 medicine men gave information for bone fracture. 19 medicinal plants were identified and documented that are used for bone fracture. Sterculia villosa one of most commonly used medicinal plants is locally known as udad is referred by 10 medicine persons to treat bone fracture. Some of them use root paste of Udad alone for curing bone fracture. Some other medicine persons add other medicinal plants along with Sterculia villosa. Sterculia villosa is one of the endangered plants due to its excessive use of its roots.
\end{abstract}

Key words: Dangs, Therapeutic, Ethnobotanical, fracture, Botanical Name, Local Name, Preparation, Application. Sterculia villosa, medicine men

\section{Introduction}

A discussion of human life on this planet would not be complete without a look at the role of plants in their life. In recent years, however, there has been a reawakened scientific interest in the fundamental role plants play in many cultures, including Medicinal purposes. This is the story of today's Ethnobotany.

Ethnobotany is the study of how people of a particular culture and region make use of indigenous plants for treating various diseases. Ethnobotanists explore how plants are used for food, shelter, medicine, clothing, hunting, religious ceremonies etc. In fact, medicine and botany have always had close ties. Many of today's drugs have been derived from plant sources. The jungles and moist deciduous forest of Dangs, in South Gujarat for example, have an extraordinary diversity of plant species and has been regarded as a treasure grove of medicinal plants.

\section{DANG: The Study Area}

\section{Location, Topography and Geomorphology}

The study tract falls between the parallels of latitude 20.33 " 53 " and 21.4 ' 52 " and the meridians of longitude $73.27^{\prime} 58^{\prime \prime}$ and $73.56^{\prime} 36^{\prime \prime}$. The Dang forest tract starts from the rugged mountain chains of Sahyadri in the east and descends on the western side extending to the edge of plains of Gujarat. The hills are mostly low and flat topped, except in the south and the East Dang where hills are rugged and higher going up to $11 \mathrm{M}$. The tract varies in elevation from 105M near Bheskhatri to 131M. above MSL on the Khandesh border in Piplaidevi Range. On the whole most of Dangs lies between elevations of 300m to 700m above MSL. Saputara - the a hill station of Gujarat is also located in the Dangs. The name Dangs means a hilly terrain. There Nis also another connotation of the word Dangs, which means a place of bamboo.

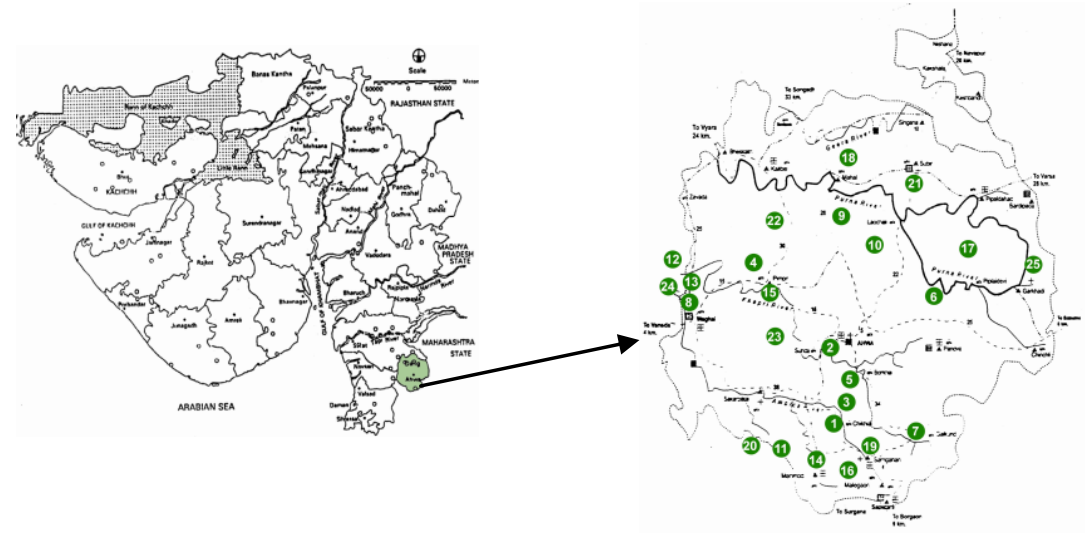




\begin{tabular}{|ll|ll|}
\hline \multicolumn{3}{|c|}{ Villages } & Visited \\
\hline 1 & Bhapkal & 14 & Nalagchod \\
2 & Bourigoutan & 15 & Pimpri \\
3 & Burapani & 16 & Ranpada \\
4 & Chichinagoutta & 17 & Sathbabla \\
5 & Chirapada & 18 & Savardakasa \\
6 & Dhuda & 19 & Shamghahan \\
7 & Dhumkal & 20 & Soupdahad \\
8 & Dungarada & 21 & Subir \\
9 & Gana & 22 & Thunduniya \\
10 & Gaygotton & 23 & Vankan \\
11 & Gundvahal & 24 & Vati \\
12 & Halmudi & 25 & Zari \\
13 & Kotba & & \\
\hline
\end{tabular}

The District of Dangs has geographical area of $1778 \mathrm{Sq}$. Km. with a population of 226,769 and 311 villages, has a sex ratio of 1007 females for every 1000 males, and a literacy rate of $76.8 \%$. The entire population is rural living. The forest area which is about $95 \%$ of the total geographical area and it comprises of 844.06 Sq. km Reserved Forest and 854.50 sq. km protected forest. Dangs contributed about $70 \%$ of the total major forest produce in the state, and about 15 lakhs bamboos produced that contribute about $50 \%$ of the state production. In this area a number of medicinal plants are found. The medicine men utilize these plants for various illness and ailments.

\section{Materials And Methods}

The research was conducted in several potential stands of the areas. For data collection, 42 traditional healers, who are native to the area, were interviewed. The information was usually imparted in local dialect, and plants were indicated with vernacular names. They also helped to find out in identifying and collecting the plants samples from the forest. Using the Botanical knowledge, with the help of Gujarat flora and authentically identified specimens available at Prof. G.L. Shah Herbarium the botanical identity was provisionally determined and further confirmed with the supervisor of the investigation. Medicine men treat many illnesses. It is very interesting to see how different medicine men use different combination of plants for treating various illnesses. One of such aliments was fracture and there are various methods to treat it. In this papers how different medicine men treat fracture cases are documented.

\section{The methods included two stages:}

The study trips were made from October to April 2013 and from July to December periodically. The field work was based on observations, interviews and guided field trips, with the help of local personals.

Extensive surveys were carried out during the field work; interviews were conducted with the medicine persons in the presence of a person who can translate the local language very efficiently. 42 informants were interviewed from 25 different villages of Dangs. By interviewing what are the common diseases, what are the treatments usually taken for a particular disease were gathered. Through questioning and discussion, different combinations of plants that are used for various diseases, how to prepare the medicine and when and how much should be consumed were documented. In this paper the treatments for bone fracture is documented. Bone fracture is very common among the people of Dangs, as climbing trees and mountain are in their daily routine. Most often people fall and fracture their bones and the medicine men that are specialised in fracture take care of curing them.

\section{Results}

During the research 42 medicine persons were met and interviewed. Out these 42 medicine person 15 were well know in Dangs for treating bone fracture cases. Usually the medicine persons use a combination of different parts of different medicinal plants to prepare medicine for a particular disease. How to prepare the medicine and what are the combination of plant parts, how to mix and apply the medicine on the fractured area are given below.

Different medicine person have different type of treatments for fracture. There are 15 different ways of treating fracture cases are mentioned below along with its local name, botanical name, plant parts used are mentioned. How to prepare the medicine mix and its application on the fracture are mentioned below.

A synoptic view of 19 plants that are used for fracture are given below in a table along with its Local Name, Botanical Name, part which is used for preparation and Application of the medicine are shown below. The photograph of Udad, Sterculia villosa is given below. 
There are 15 different ways of treating bone fracture which are informed by 15 medicine persons are given below. Medicinal plants local name, botanical name, parts used along with it preparation and its application.

\section{Udad, Sterculia villosa, Root}

Preparation: Root is crushed and made into a paste till it becomes jelly like.

Application: After setting the bone apply this paste where it is fractured. Application is once a day, preferably in the morning.

\section{Dhudari, Euphorbia hirta, Root}

Polas, Butea monosperma, Bark

Preparation: Dudari root and Polas bark are crushed together and applied on the fractured place. Also the mixture of the two is crushed well and the extract is removed

Dosage: Half a cup of the extract is taken twice a day; in the morning on empty stomach, and in the evening after the meals.

\section{Nigundo, Vitex nigundo, Leaves}

Preparation: The leaves are crushed with salt and made into a paste,

Application: Bandaged with it after setting the bones properly.

\section{Sagava (Shegalu), Moringa oleifera, Bark}

Preparation: The leaves are crushed and made into a paste.

Application: Bandaged with it after setting the bones properly.

\section{Bhootjad, Ailanthus excelsa, Bark}

Madhul, Lannaea coromandelica, Bark

Tan velo, Cocculus hirsutus, leaves

Ranbhendi, Azanza lampas, Root

Liliamba (Haldar), Curcuma longa, Rhizome

Preparation: A mixture of all these is crushed well and made into a paste.

Application: Apply on to the fractured part 2-3 times a day and bandage it.

\section{Udad, Sterculia villosa, Root}

Patherphodi, Tridax procumbens, the whole Plant

Preparation: These plant parts are crushed and made into a paste with lakh mati.

Application: Bandage with the paste after setting the bone properly.

\section{Udad, Sterculia villosa, Root}

\section{Amba haldar, Curcuma amada, Rhizome}

Preparation: The mixture of both is crushed and made into a paste.

Application: Bandaged with the paste after setting the bones properly.

\section{Udal (Udad), Sterculia villosa, Root}

Digad, Dioscoria oppositifolia, Rhizome

Karbat, Grewia hirsuta, Root

Preparation: All the roots are crushed together and made into a paste.

Application: Bandaged with the paste after setting the bones properly. After 7-8 days if it is needed the first bandage is removed and another bandage is made.

\section{Kandol, Sterculia urens, Bark \\ Udada, Sterculia villosa, Bark \\ Nilisoti, Dalbergia volubilis, Leaves}

Rakath rohidi, Tecomella undulata Bark Preparation: Equal portions of the above mentioned plant parts are dried and powdered. Then the powder is soaked in water and made into a paste.

Application: The paste is applied on the fracture after setting the bone properly.

\section{Udada, Sterculia villosa, Root}


Madhul, Lannaea coromandelica, Root

Nimbara, Melia composita, Bark

Choki bendi, Hibiscus esculentus Root

Kakod, Garuga pinnata, Bark

Preparation: Equal portions of these plant parts together with a crab is crushed and made into a paste.

Application: Bandage is made with the paste and Bamboo strips are used as support.

Bandage is removed after 8 days. If it is needed one more bandage is made.

11. Kali bondar, Lagerstroemia parvifolia, Leaves

Preparation: These leaves are crushed and mad into a paste.

Application: Bandaged with it after setting the bone properly.

12. Udada, Sterculia villosa, Root

Digad, Dioscoria oppositifolia, Tuber

Preparation: These plant parts are crushed and made into a paste.

Application: Bandaged with it after setting the bone properly.

\section{Madhul, Lannaea coromandelica, Bark}

Elebivula, Millettia racemosa, Bark

Udala, Sterculia villosa, Root

Preparation: These plant parts are crushed and made into a paste.

Application: Bandaged with it after setting the bone properly.

\section{Rakath rohidi, Tecomella undulata, Bark}

Udal, Sterculia villosa, Root

Kakod, Garuga pinnata, Bark

Madhul, Lannaea coromandelica, Bark

Preparation: Equal portions of these plant parts together with a crab is crushed and made into a paste.

Application: Bandage is made with the paste and Bamboo strips are used as support.

Bandage is removed after 8 days. If it is needed one more bandage is made.

\section{Polas, Butea monosperma, Root}

Kahndol, Sterculia urens, Bark

Udada, Sterculia villosa, Root

Haldar Curcuma longa, Rhizome

Preparation: Equal portions of the above mentioned plant parts are crushed, dried and powdered. The powder is made into a paste by adding some water.

Application: Bandage with the paste, Bamboo strips are used as support.

The Bandage is removed after 8 days. If needed one more bandage is made.

\section{Discussion}

Bone fracture is one of the therapeutic practices that are practiced by the medicine men in Dangs Dt. And Sterculia villosa is the main ingredient that is used for it. So it is important to find out what are it chemical constituents and other components present in Sterculia villosa that help to cure bone fracture can be further investigated.

\section{Summary And Conclusion}

From this study come to know what are medicinal plants used among the tribals for bone facture. The study revealed that Sterculia villosa is one of the main plants used for bone fracture. About 10 medicine men specified this plant alone or with other medicinal plants to treat bone fracture. This study also reveals that Sterculia villosa is one of the endangered plants in Dangs Dt. Its root is mainly used for bone fracture and many other medicinal purposes. By using the roots, the plant is destroyed totally thus there is no chance of further development or its propagating through seeds.

\section{Acknowledgement}

Authors are thankful to the Jesuits fathers and Vedruna sisters who are working at Subir, Pimpri and Shamghahan at Dang Dt. for making the arrangement to visit the medicine men along with a local guide and also facilitating different forests visits to identify the plants. 


\section{Reference/ Bibliography}

[1] Arora R.K., Ethnobotany and its role in the conservation and use of plant genetic resources in India, Ethnobotany, 9,6-15 (1997)

[2] Bharara, L.P. (1993). Socio-economic aspects of Banni pastoralists and factors effecting changes in their perceptions towards the future. In: Proceeding of the Workshop on Trans-human Pastroralism in Gujarat. Anand, Gujarat, India. Pp. 1-7.

[3] Bhogaonkar P.Y. and Deokule S., Some useful ethnomedicinal plants of Korku of Melghat region (MS), Ethnobotany, 12(1-2), 1619 (2002)

[4] Daniels, R.J.R. \& Jayanthi, M. (1996). Biology and conservation of endangered plants: The need to study breeding systems. Tropical Ecology. 37 (1): 39-42.

[5] Dixit, A.M. \& Subba Rao, S.V. (2000). Observation on distribution and habitat characteristics of Gugal (Commiphora wightii) in the arid region of Kachchh, Gujarat (India). Tropical Ecology. 41 (1): 81-88.

[6] Dharmani,P. and Patil,G.(2006): Exploring Indian medicinal plants for antiulcer activity. Indian J

[7] Eilu, G. \& Bukenya-Ziraba, R.. (2004). Local use of climbing plants of Budongo forest reserve, Western Uganda. Journal of Ethnobiology. 24 (2): 307-327.

[8] Gadgil, M., Rao P.R.S., Utkarsh, G. \& Chhate, A. (2000). New meaning for old knowledge: The people's biodiversity registers programme. Ecological Applications. 10: 1307-1317.

[9] Ibrar M., Responsibilities of ethnobotanists in the field of medicinal plants, In Proceeding of Workshop on Curriculum Development in Applied Ethnobotany. Ethnobotany Project, WWF Pakistan, 34-D/2:16-20 (2002)

[10] Ilahi I., Iqbal Z. and shafiq-ur -rehman, Cistanche tubulosa (Schenk) R. Wight, An important medicinal plant occurring in sand dunes of Karak N W F P Pakistan, Pak. J. Bot., 42(1), 537-547 (2010)

[11] Nadkarni K.M., Indian plants and drugs with their medicinal properties and uses. Asiatic publishing House, New Delhi (2001)

[12] Pranjali J.D. and Pei S.J., Ethnobotanical approaches of traditional medicine studies some experiences from Asia, 39, 74-79 (2001)

[13] Indian Oil Corporation Ltd. (IOCL), Gujarat Refinery, Vadodara, Gujarat. 28 p.

[14] Thaker, J.I., (1926). Plants of Kutch and their Utilities. Rajkot, Gujarat, India.

[15] Vyas, S.P. (2001). Ethno-medicinal plants of Kachchh. Indian J

[16] $\wedge$ http://www.censusindiamaps.net/page/India_WhizMap/IndiaMap.htm

[17] $\wedge$ a b c d e f g "District Census 2011". Census2011.co.in. 2011. Retrieved 2011-09-30.

[18] Reddy A R Flora of Dharampur forest, PhD Thesis, (Sardar Patel University, Vallabh Vidyanagar, Gujarat), 1986

[19] Thresia at al., Therapeutic and Ethnobotanical Investigations in Dangs Dt. Gujarat state. India. World ournal of Science 2013; 1(2): $118-132$

[20] Nirmal Kumar JI, Hiren Soni \& Rita N Kumar, Ethnobotanical values of certain plant species of Dang forest, extreme northern parts of Western Ghats, South Gujarat, India, J Curr Biosci,2 (1) (2004) 63-74.

[21] Nirmal Kumar at el., Studies on plant species used by tribal communities of Saputara and Purna forests, Dangs district, Gujarat.Indian Journal of Traditional Knowledge; Vol. 6(2), April 2007, pp. 368-374

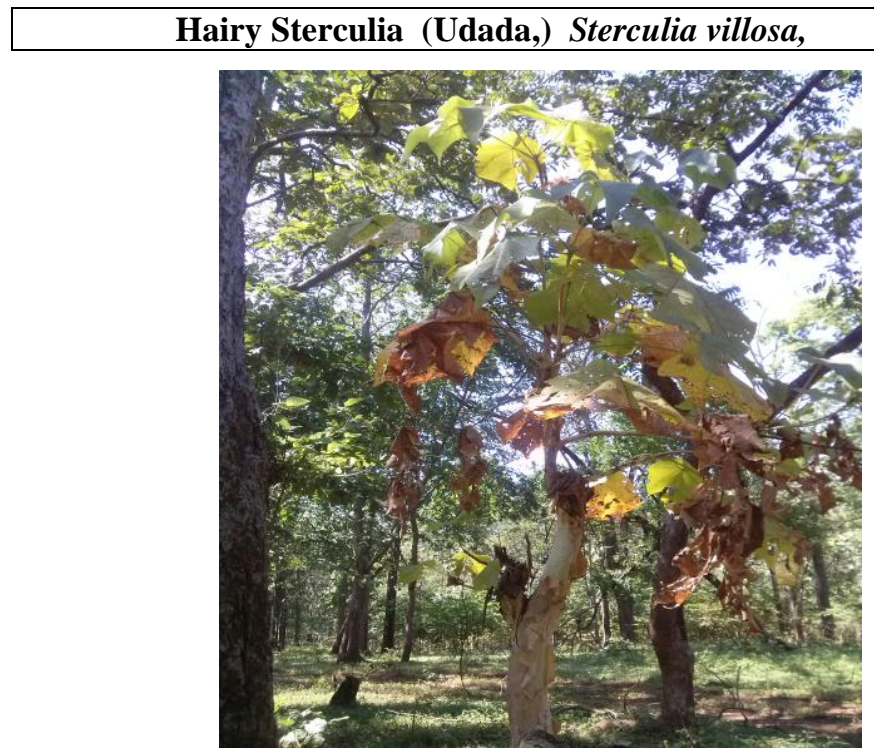

Synoptic View Of Medicinal Plants Used For Bone Fracture.

\begin{tabular}{|l|l|l|l|l|l|l|}
\hline Sr. No & Botanical Name & \multicolumn{1}{|c|}{ Family } & Local Name & Habit & Parts Used & English Name \\
\hline 1. & Ailanthus excelsa & $\begin{array}{l}\text { Simaroubacea } \\
\mathrm{e}\end{array}$ & $\begin{array}{l}\text { Bhoot jad, } \\
\text { harduso, } \\
\text { Arduso }\end{array}$ & Tree & Bark & Indian Tree of Heaven, \\
\hline 2. & Azanza lampas & Malvaceae & $\begin{array}{l}\text { Ran Bhendi, } \\
\text { Bangali }\end{array}$ & Shrub & Root & $\begin{array}{l}\text { Ban Kapas, Common Mallow } \\
\text { African chewing gum, azanza, } \\
\text { quarters, snot apple, tree } \\
\text { hibiscus, wild hibiscus }\end{array}$ \\
\hline 3. & $\begin{array}{l}\text { Butea } \\
\text { monosperma }\end{array}$ & Fabaceae & Polas, Kaharo & Tree. & Bark, Root & Flame of the Forest \\
\hline 4. & Cocculus hirsutus & $\begin{array}{l}\text { Menispermace } \\
\text { ae }\end{array}$ & Tan vel & Climber & Leaves & Broom creeper, Ink berry \\
\hline
\end{tabular}


Ethno-Therapeutic Remedies for Bone Fracture, Dang Dt. Gujarat. India.

\begin{tabular}{|l|l|l|l|l|l|l|} 
5. & Curcuma amada & Zingiberaceae & $\begin{array}{l}\text { Ambahaldar, } \\
\text { Lili amba }\end{array}$ & Herb & Rhizome & mango ginger \\
\hline 6. & Curcuma longa & Zingiberaceae & Halder & Herb & Rhizome & Turmeric \\
\hline 7. & $\begin{array}{l}\text { Dalbergia } \\
\text { volubilis }\end{array}$ & Fabaceae & Nilisotti & Climber & Leaves & Climbing Dalbergia \\
\hline 8. & $\begin{array}{l}\text { Dioscorea } \\
\text { oppositifolia }\end{array}$ & Dioscoreaceae & Digad & Climber & Tubers & Chinese yam \\
\hline 9. & Garuga pinnata & Bruseraceae & Kakod & Tree & Bark & Garuga, grey downy balsam \\
\hline 10. & Grewia hirsuta & Tiliaceae & $\begin{array}{l}\text { Karbat, } \\
\text { Kardhamani }\end{array}$ & Shrub & Root & Veronicalolia. \\
\hline 1. & $\begin{array}{l}\text { Hibiscus } \\
\text { esculentus }\end{array}$ & Malvaceae & $\begin{array}{l}\text { Bhendi, } \\
\text { Choki bhendi }\end{array}$ & Herb & Root & Okra, lady's fingers \\
\hline 12. & $\begin{array}{l}\text { Lannaea } \\
\text { coromandelica }\end{array}$ & Anacardiaceae & $\begin{array}{l}\text { Madhul, } \\
\text { Modad }\end{array}$ & Tree & Bark, Root & $\begin{array}{l}\text { Indian Ash Tree Hill Neem, } \\
\text { Malabar }\end{array}$ \\
\hline 13. & Melia composita & Meliaceae & $\begin{array}{l}\text { Nimbaro, } \\
\text { Limbaro }\end{array}$ & Tree & Bark & $\begin{array}{l}\text { Hill Neem, Malabar Neem, } \\
\text { Common Bead tree }\end{array}$ \\
\hline 4. & Millettia racemosa & Fabaceae & $\begin{array}{l}\text { Ale bibula, } \\
\text { Bibulavel }\end{array}$ & Climber & Bark & Vietnamese \\
\hline 15. & Moringa oleifera & Moringaceae & $\begin{array}{l}\text { Shegu, } \\
\text { Sargava }\end{array}$ & Tree & $\begin{array}{l}\text { Bark, Small } \\
\text { plant }\end{array}$ & $\begin{array}{l}\text { Horseradish tree, Radish tree, } \\
\text { Drumstick tree, Mother's Best } \\
\text { Friend, West Indian ben. }\end{array}$ \\
\hline 16. & Sterculia urens & Sterculiaceae & $\begin{array}{l}\text { Kandol, } \\
\text { Kadavai }\end{array}$ & Tree & Bark & Indian tragacanth, gum karaya, \\
\hline 17. & Sterculia villosa & Sterculiaceae & Udad & Tree & Root & Hairy Sterculia \\
\hline 8. & $\begin{array}{l}\text { Tecomella } \\
\text { undulata }\end{array}$ & Bignoniaceae & Rakath rohidi & Tree & Bark & $\begin{array}{l}\text { Roheda, Honey Tree, Desert } \\
\text { Teak, Marwar Teak }\end{array}$ \\
\hline 19. & $\begin{array}{l}\text { Tridax } \\
\text { procumbens }\end{array}$ & Asteraceae & Patterpui & Herb & Whole Plant & $\begin{array}{l}\text { Tridax Daisy, Coat Buttons, } \\
\text { Mexican Daisy }\end{array}$ \\
\hline
\end{tabular}

